\title{
Measuring the Concept of Deliberative Democracy in the Indonesian Election Supervision System
}

\author{
Kamal Fahmi Kurnia ${ }^{1}$ \\ \{kamal.fahmi1405@gmail.com $\left.{ }^{1}\right\}$ \\ Fakultas Hukum, Universitas Sang Bumi Ruwa Jurai, Bandar Lampung, Indonesia ${ }^{1}$
}

\begin{abstract}
The administration of fair and honest elections is a constitutional mandate. The supervision system in elections is a very important part of realizing fair and fair elections for all parties. The concept of deliberative democracy is more attractive to be applied in various government policies because it is considered capable of realizing the true goals of democracy. This article aims to analyze the application of the concept of deliberative democracy in the election supervision system in Indonesia. Based on the results of the analysis, it shows that the main concept of deliberative democracy is the existence of public space provided for the public to participate in a public policy. Furthermore, the concept of deliberative democracy has also been accommodated in the election supervision system in Indonesia. This can be seen from the existence of a participatory monitoring room. Participatory monitoring rooms provide an opportunity for the public to participate in election supervision.
\end{abstract}

Keywords: deliberative democracy, supervision system, general election.

\section{Introduction}

The holding of general elections is an important part of a democratic country. Juridical, the regulation of general election in Indonesia has a constitutional basis in the 1945 Constitution of the Republic of Indonesia. In the 1945 Constitution of the Republic of Indonesia it is explained that the General Election is held every 5 (five) years and is carried out by promoting principles of direct, general, free, confidential, honest and fair [1]. The provisions for holding general elections are further regulated in Law Number 7 of 2017 concerning General Elections. In this paper, the implementation of the General Election includes the General Election of the President and Legislative Members.

The organizers of general elections in the general election system in Indonesia are the General Election Commission, the General Election Supervisory Body, and the General Election Organizer Honorary Council. The General Election Supervisory Agency as one of the General Election organizers has a supervisory function on the implementation of general elections in Indonesia. Supervision System in the administration of general elections is a very important part to be implemented. The General Election Supervisory Agency as a supervisory agency, is the part 
that provides control over the implementation of general elections. As an institution, general election supervision is carried out in stages from the central level to the polling stations.

The general election supervision system covers the stages of the recruitment of election supervisory members to the supervisory process carried out by election supervisory institutions in order to provide control over the implementation of general elections in Indonesia. The supervision system in general elections has been regulated in several laws and regulations. The technical arrangements for the general election supervision process are regulated in several Regulations of the General Election Supervisory Agency.

The conception of the general election supervision system in Indonesia has been regulated from the process of institutional formation, selection of supervisory candidates, prevention in the framework of preventive efforts to hold general elections, to the process of prosecuting alleged violations. The supervision system in general elections must be able to provide assurance of supervision that can achieve the objectives of holding general elections in accordance with the 1945 Constitution of the Republic of Indonesia [2].

Deliberative Democracy as a concept is not a new idea in the administration of government policy. So far, the application of the concept of deliberative democracy in every government policy has become the most promising consensus in the context of realizing the true goal of democratic life. The general election supervision system as a government policy is also expected to accommodate the concept of deliberative democracy. In this case, has the general election supervision system in Indonesia accommodated the concept of deliberative democracy in its implementation? This study aims to conduct a juridical analysis related to the application of the concept of deliberative democracy in the general election supervision system in Indonesia. From the results of the juridical analysis carried out, it is expected to provide recommendations as an effort to establish an effective supervisory system in providing control over the implementation of general elections. In the following, this paper will analyze the main concepts of deliberative democracy and analysis related to the application of the concept of deliberative democracy in the election supervision system in Indonesia.

\section{Literature Review}

\subsection{Democracy Theory}

In understanding the main concepts of democracy, there are three theories of democracy in Gould's classification, namely 1) the liberal individualism model, 2) the pluralist model, and 3) the holistic socialism model [1]. The theory of democracy is a model of liberal individualism, this model describes democracy as a protector of people from the powers of government power, and places the government as a protector of the freedom of all people from threats and disturbances. This democratic model wants universal equality for all people and equal rights for all these people in the political process. This view is characterized by "one person one vote" (one man one vote). [3]

The pluralist theory of democracy is a theoretical model that has emerged in the writings of such theories as Madison, Dewey, Dahl and Berelson. This theory is the opposite of abstract individualism which emphasizes the self-interest of independent individuals. In this case pluralism focuses attention on group interests as an aggregation of individual interests, and their emergence 
will result in conflict in the political process. Thus, political democracy is interpreted as a government system that mediates conflict (competition) in order to obtain social balance [3]. According to this theory political democracy maximizes the representation of individuals whose interests may not be adequately represented by the power of the group to which they belong. This theory also states that pluralism protects the freedom of choice of individuals by providing political alternatives that represent a plurality of interest groups or parties.

The social relationships that are a consequence of this model are more of intergroup relationships than inter individual relationships. Relationships are external in nature, in the sense that each group defines something by referring to fixed or standard interests, which basically do not change when relationships with other groups take place.

The third model of view, holistic socialism, is an approach that emphasizes economic democracy and appears to respond to the rejection of the reality of social and economic relations raised by liberal individualism. This general view is represented by two main types of theory. The first theory tends to understand economic democracy as a way of distributing goods and opportunities more equitably in the context of forms of political democracy. it is more of a liberal than a socialist view. The second theory emphasizes the need for democracy in controlling production and distribution, traditionally this is a general socialist theory[3].

Gould argues that liberal democracy emphasizes individual participation in the decisionmaking process for economic and political life (although the ultimate goal is social justice). Regarding socialist theory, on the other hand, it understands the community or society as a whole as the main thing, and sees forms of government (politics) as things that are subordinate to economic life. The concept of holistic economic democracy is the backbone of the holistic theory of socialism [3].

Democracy as a system has been used as an alternative in various social and state activities in several countries. As admitted by Moh.Mahfud.MD, and two reasons for choosing democracy as a system of society and state. First, almost all countries in the world have made democracy a fundamental principle; second, democracy as the principle of vigor has essentially provided direction for the role of society in administering the state as the highest organization. Therefore, it requires correct knowledge and understanding of citizens about democracy.[4]

Meanwhile, the definition of democracy in terms put forward by some experts is as follows:

a. According to Joseph A. Schmeter, democracy is an institutional plan to reach political decisions in which individuals gain power to decide how to compete competitively for the votes of the people.[5]

b. Sidney Hook argues democracy is a form of government in which important government decisions are directly or indirectly based on majority agreement given freely from adult people.[6]

c. Philippe Schmitter and Terry Lynn Karl state democracy as a system of government in which the government is held accountable for their actions in the public sphere by citizens who act indirectly through competition and cooperation with their elected representatives.[7]

d. Henry B. Mayo stated that democracy as a political system is a system which shows that general policy is determined on the basis of a majority by representatives who are effectively 
supervised by the people in periodic elections based on the principle of political equality and held in an atmosphere of guaranteed political freedom. [8]

e. Affan Gafar defines democracy in two forms, namely normative and empirical. Normative democracy is a democracy that a country would ideally like to do. Meanwhile, empirical democracy is democracy in the form of practical politics [1].

The meaning of democracy as the basis for living in a society and as a state implies that it is the people who provide provisions in matters concerning their lives, including in assessing state policies, because these policies will determine the lives of the people. Thus a country adhering to a democratic system is a country that is organized based on the will and will of the people [8].

\subsection{Main Concept of Deliberative Democracy}

The term deliberative democracy was first introduced by J.M. Bessette in 1980 . Etymologically the term "deliberation" comes from the Latin "deliberation" which means consultation, considering, or deliberation. In its development, the term deliberative democracy was developed and popularized by Jurgen Habermas. The basis of Jurgen Habermas's thought in developing the concept of deliberative democracy departs from one of the developing concepts of democracy, namely the procedurals democracy model [9].

In its development, there is no standard model to explain the concept of deliberative democracy. This can be caused by the space that is deliberately given for contextual interpretation according to the times [10]. The practice of the concept of deliberative democracy is actually just an attempt to position the socio-political order to suit the public's needs in touching the effects of policies issued by the State and therefore it can only be assessed when it comes into contact with the context. When he speaks in reality and mingles in interactions that occur in the non-theoretical realm. All of them agree on several characteristics to refer to the concept of deliberative democracy, namely: participation, freedom and equality (liberty and equality), an interest in the common good (appeals to the common good), the desire to vote (need for voting) [11].

The basic conception of the concept of deliberative democracy according to Bernard Manin, "... the source of legitimacy is not the predetermined will of individuals, but rather the process of its formation, that is, deliberation itself."[12] In other terms, the democratic model according to Bernard Manin assumes that no individual value and perspective is self-correct without first going through a process of dialogue and agreement with other individuals.

In explaining the concept of deliberative democracy further, Habermas stated that a government decision or policy has strong legitimacy if it has gone through a process of testing or discourse, where all issues are discussed together, especially by parties directly involved with the issue in an equal position and without pressure from other parties. 5 Meanwhile, Habermas said that the "discourse" could take place in a stage known as the public sphere (public space). Habermas interprets the public space as the essence of the conditions of communication in which a form of discursive opinion and aspirations of a public consisting of citizens can take place.[11] Basically, the conception of public space offered by Habermas is used as an instrument in accommodating the aspirations of the community.

Deliberative democracy emphasizes the importance of public participation which is dialogical and synthetic in nature and jointly strives to find truths rooted in facts, cares for the 
interests of society and is not doctrinaire. Deliberative democracy accommodates the weaknesses of the voting mechanism created by liberal democracy which places the winner of the most votes as the party "entitled to determine collective action".[13] Its deliberative nature becomes the legitimate of this model, government policies are tested through a broad public consultation process. Automatically, this broad public consultation process increases public participation in democracy.

The concept of deliberative democracy wants to increase the intensity of citizen participation in every decision-making process and government policy, so that decisions and policies produced by the governing party are closer to the expectations of the governed.[14] Citizen Involvement in every government policy is the core of deliberative democracy. Hardiman tries to summarize the essence of the teachings of the concept of deliberative democracy, namely that all government policy products made by the State must go through aspirations by involving the public, so that the policies made are in accordance with the existing conditions of society.[14] Another opinion states that deliberative democracy is a democratic model that considers the political legitimacy of every process of policy-making and the implementation of government to come from public deliberation between citizens who are free and equal.

Deliberative democracy in Indonesia explicitly began to emerge after the New Order era was passed. This may be due to conditions of openness and freedom (both in terms of thought and practice) that were not found (possible) during the New Order era. Indeed, the idea of deliberative democracy has been popular before (even when the country was only formed by the founding fathers), but that does not mean that it can be theoretically equated between the idea of deliberative democracy and the idea of deliberative democracy.

\section{Methods}

This type of research is normative legal research. Data sources used are secondary data sources consisting of primary legal material; secondary legal material; and tertiary legal material. This study was analyzed descriptively qualitatively, which is collecting and selecting legal materials in accordance with the problem under study, then described so as to produce a picture or conclusion that is in accordance with the actual situation so as to be able to answer all existing problems. This research uses a legal approach in the form of a statutory approach because the main material to be analyzed is the Law on the Election Supervision System and the Law on General Elections.

\section{Result And Discussion}

\subsection{Legal Basis for General Election Supervision System in Indonesia}

The legal basis for the general election supervision system in Indonesia in stages according to the order of the laws and regulations are:

1. Article 22E of the 1945 Constitution of the Republic of Indonesia;

2. Law Number 7 Year 2017 concerning General Elections;

3. Regulations of the Election Supervisory Agency of the Republic of Indonesia. 
Several provisions related to the general election supervision system contained in Law Number 7 of 2017, are:

1. Institutionally, the general election supervisory agency in Indonesia is regulated in Article 89 - Article 92 Law Number 7 Year 2017 concerning General Elections.

2. Article 94 letter d, regulates one of the duties of the General Election Supervisory Body, namely, increasing public participation in election supervision.

3. Article 98 paragraph (1) letter d, regulates one of the tasks of the Provincial General Election Supervisory Agency, namely, increasing public participation in election supervision in provincial areas.

4. Article 102 paragraph (1) letter $\mathrm{d}$, regulates one of the duties of the regional / municipal election supervisory agency, namely, increasing public participation in election supervision in regency / municipal areas.

5. Article 105 letter a number 4, regulates one of the tasks of the District election supervisory committee, namely, increasing public participation in election supervision in sub-district areas.

6. Article 119 of Law Number 7 of 2017 regulates the mechanism for recruiting members of the General Election Supervisory Agency,

a. In paragraph (1), it states:

The selection team as referred to in Article 118 carries out its duties openly by involving public participation.

b. Elucidation of Article 119 Paragraph (1) of Law Number 7 of 2017, namely:

What is meant by "involving public participation" is giving the public an opportunity to submit written responses and input to a candidate member of the General Election Supervisory Body.

c. In paragraph (3) letter g, it states:

Announcing through the national mass media the list of names of prospective candidates for members of the General Election Supervisory Board who have passed the written selection and psychological tests to obtain input and responses from the public;

7. Article 125 of Law Number 7 of 2017 regulates the mechanism for recruiting members of the Provincial General Election Supervisory Board.

a. In paragraph (1), it states:

The selection team as referred to in Article 124 carries out its duties openly by involving public participation.

b. Elucidation of Article 125 Paragraph (1) of Law Number 7 of 2017, namely:

What is meant by "involving public participation is giving the public the opportunity to submit written responses and input to candidates for members of the Provincial General Election Supervisory Body. 
c. In paragraph (3) letter $\mathrm{g}$, it states:

Announcing through the local mass media the list of names of prospective Provincial election supervisory body members who have passed the written selection and psychological tests to get input and responses from the public;

8. Article 129 of Law Number 7 of 2017 regulates the mechanism for recruiting members of the Regency / City election supervisory body.

a. In paragraph (1), it states:

The selection team as referred to in Article 128 carry out their duties openly by involving public participation.

b. Elucidation of Article 129 Paragraph (1) of Law Number 7 of 2017, namely:

What is meant by "involving public participation" is giving the public the opportunity to submit written responses and input to candidates for members of the Regency / Municipal election supervisory body.

c. In paragraph (3) letter g, it states:

Announcing through the local mass media the list of names of prospective candidates for members of the Regency / City General Election Supervisory Agency who have passed the written selection and psychological tests to obtain input and responses from the public;

9. Article 454 of Law Number 7 of 2017, states:

a. In paragraph (1), it states:

Election violations originate from findings of Election violations and reports of Election violations.

b. In paragraph (2), it states:

Election violation reports are direct reports of Indonesian citizens who have the right to vote, election contestants, and election observers to the Election Supervisory Board, Provincial Election Supervisory Body, Regency / Municipal Election Supervisory Board, District Election Supervisory Committee, Village / Village Election Supervisory Committee, Foreign election supervisory committee, and / or polling station supervisors at each stage of the Election.

\subsection{The Concept of Deliberative Democracy in the General Election Supervision System in Indonesia}

In the previous discussion, it was explained that the notion of deliberative democracy gave important meaning to decision-making processes or procedures that emphasized citizen involvement. Public participation with direct community involvement in a political policy that the government makes is the core of deliberative democracy. In practice, community participation to be involved in government policies / decisions can be channeled through existing public spaces.

In the context of the application of democracy in Indonesia, it raises a question, whether so far deliberative democracy has been accommodated by the Indonesian government in any given 
policies. More specifically, when looking at the supervision system in the implementation of general elections in Indonesia.

As previously explained, the general election supervision system includes the stages of the recruitment of election supervisory members to the supervision process carried out by election supervision institutions in order to provide control over the implementation of general elections in Indonesia. From the research results previously described, several provisions in Law Number 7 of 2017 serve as a juridical basis in the implementation of the general election supervision system in Indonesia.

The general election supervision system is institutionally regulated in Articles 89 - 92 of Law Number 7 of 2017. In this article, it is explained that the institutional form of general election supervisors is arranged in stages from the central level to supervision at the polling station level. The General Election Supervisory Board is the supervisor of general elections at the central level. The Provincial Election Supervisory Agency is the general election supervisory agency at the provincial level. The regency / municipal election supervisory agency is the general election supervisory agency at the district / city level. The District General Election Supervisory Committee is a supervisory committee at the sub-district level. The Village General Election Supervisory Committee is a supervisory committee at the village level. Polling Station Supervisor is a supervisory officer at each polling station.

Articles 94, 98, 102 and 105 of Law Number 7 of 2017 contain provisions on one of the duties of the general election supervisory agency to increase public participation in supervision at every level. The existence of one of the tasks given to the general election supervisory agency is related to increasing public participation, the authors consider it an effort to open up public space in the monitoring process.

Article 119 of Law Number 7 of 2017 regulates the stages in recruiting candidates for members of the General Election Supervisory Agency. The recruitment of prospective members of the General Election Supervisory Body is carried out by a previously formed selection team. Article 119 paragraph (1) of Law Number 7 Year 2017 provides rules for the selection team to involve public participation in selecting candidates for the General Election Supervisory Body. The elucidation of these provisions states that what is meant by involving community participation is to provide opportunities for the public to submit written responses and input to prospective members of the General Election Supervisory Board. Public participation in the form of responses and input to the selection process for candidate members of the General Election Supervisory Body will take place after the announcement of a candidate for the General Election Supervisory Board who has passed the written test and psychological test. This is regulated in Article 119 paragraph (3) letter g of Law Number 7 of 2017 concerning General Elections.

Article 125 of Law Number 7 of 2017 regulates the stages in recruiting candidates for members of the Provincial General Election Supervisory Board. The stages of recruiting candidates for members of the Provincial Election Supervisory Agency are not substantially different from the stages of recruiting candidates for members of the General Election Supervisory Agency. The recruitment of candidates for members of the Provincial General Election Supervisory Body is carried out by a selection team formed by the General Election Supervisory Agency. Similar to the selection team in selecting candidates for the General Election Supervisory Body, the selection team for candidate members of the Provincial General Election Supervisory Agency must also involve public participation in the selection process. Article 129 of Law 
Number 7 of 2017 regulates the stages in recruiting candidates for members of the Regency / City General Election Supervisory Board. The recruitment of candidates for members of the Regency / Municipal General Election Supervisory Agency is carried out by a selection team formed by the Provincial General Election Supervisory Agency. Similar to the recruitment of candidates for members of the General Election Supervisory Agency and the Provincial Election Supervisory Agency, Article 129 paragraph (1) requires the selection team to involve the participation of the public in conducting the selection.

The process of selecting candidates for members of the general election supervisory agency is a political process for government policies that will issue political decisions resulting from the selection. Some of the provisions above have explicitly provided opportunities for the public to participate in the selection process. The form of participation regulated in these provisions is in the form of input or responses submitted to prospective members of the general election supervisor who pass the written and psychological tests and will then take the interview test. The form of participation regulated in these provisions by Jurgen Haberman is referred to as the public space in determining government political policy. The existence of public space provided juridical can be interpreted as a form of application of the concept of deliberative democracy in the process of selecting candidates for members of general election supervisory bodies in Indonesia.

Article 454 of Law Number 7 Year 2017 can also be said to be an effort to provide public space for the community in carrying out its supervisory function. In this article, related to the handling of violations, the general election supervisory agency can handle violations originating from violation reports or from findings of supervisors. The following provisions explain that a violation report is a direct report to the public when it finds an alleged violation in the holding of general elections. The public has the legal standing to be able to report violations in holding general elections. This provision can be interpreted as saying that the public is given space to participate in supervising the holding of general elections. The existence of space to participate in the supervision can be interpreted as an effort to apply the concept of deliberative democracy to the process of overseeing the implementation of general elections.

\section{Conclusion}

The legal basis for holding general elections in Indonesia is Law Number 7 of 2017 concerning General Elections. The general election supervision system is an important part of ensuring the implementation of an honest and fair general election. In understanding the main concept of deliberative democracy, the existence of public space provided for the public in providing participation in a public policy is the main requirement. Public space as a participatory effort provided by every citizen ensures that communication between citizens and the government is always accommodated in every policy. Furthermore, the concept of deliberative democracy has also been accommodated in the election supervision system in Indonesia. The concept of deliberative democracy that is accommodated in the election supervision system in Indonesia can be seen from the existence of a participatory monitoring room. Participatory supervision is a form of supervision provided to every citizen to participate in the process of supervising the implementation of general elections in Indonesia. In practice, the participatory supervision room 
as a contribution to the concept of deliberative democracy has not been fully utilized, due to the lack of public understanding of the participatory supervision space.

\section{References}

[1] S. S. Hadiwijoyo, Negara, demokrasi, dan civil society. Graha Ilmu, 2012.

[2] K. F. Kurnia, T. Terina, and D. Mahardika, "The Authority of Constitutional Court in General Election Results: Is It Powerful or Meaningless?," in International Conference on Law Reform (INCLAR 2019), 2020, pp. 130-134.

[3] C. C. Gould and S. Wibawa, Demokrasi: ditinjau kembali. Tiara Wacana Yogya, 1993.

[4] M. Mahfud, Demokrasi dan konstitusi di Indonesia. Rineka Cipta, 2000.

[5] J. A. Schumpeter, Capitalism, socialism and democracy. routledge, 2013.

[6] D. Rosyada, "Demokrasi, Hak Asasi Manusia, dan Masyarakat Madani," Jakarta, Prenada Media, 2003.

[7] P. C. Schmitter, "Making sense of the EU: Democracy in Europe and Europe's democratization," $J$. Democr., vol. 14, no. 4, pp. 71-85, 2003.

[8] D. Winarno, Paradigma baru pendidikan kewarganegaraan: panduan kuliah di perguruan tinggi. Bumi Aksara, 2006.

[9] J. Bohman, "Deliberative democracy and the epistemic benefits of diversity," Episteme A J. Soc. Epistemol., vol. 3, no. 2, pp. 175-191, 2006.

[10] M. Faishal, "Institusionalisasi Demokrasi Deliberatif di Indonesia: Sebuah Pencarian Teoretik," J. Ilmu Sos. dan Ilmu Polit., vol. 11, no. 1, pp. 1-30, 2007.

[11] F. B. Hardiman, Demokrasi deliberatif: menimbang negara hukum dan ruang publik dalam teori diskursus Jurgen Habermas. Kanisius, 2009.

[12] B. Manin, "On legitimacy and political deliberation," Polit. Theory, vol. 15, no. 3, pp. 338-368, 1987.

[13] A. Latipulhayat, "Demokrasi Deliberatif: Dari Wacana ke Kerangka Hukum," Padjadjaran J. Law, vol. 3, no. 2, 2016.

[14] F. Muzaqqi, Diskursus Demokrasi Deliberatif di Indonesia. Airlangga University Press, 2019. 